\title{
Perante a Pneumônica \\ a epidemia e as respostas das autoridades de saúde pública e dos agentes políticos em Portugal $(1918-1919)^{\star}$
}

\section{Tackling the Flu}

the epidemic and the responses from the public health officers and the political agents in Portugal (1918-1919)

\author{
JOSÉ MANUEL SOBRAL \\ Investigador Auxiliar no Instituto de Ciências Sociais da Universidade \\ de Lisboa Doutor em Antropologia, Licenciado em História \\ Av. Professor Aníbal de Bettencourt, n. ${ }^{\circ} 9,1600-189$ Lisboa \\ jose.sobral@ics.ul.pt \\ MARIA LUÍSA LIMA \\ Professora Associada com Agregação no ISCTE e \\ Investigadora no Centro de Investigação e Intervenção Social. \\ Doutor em Psicologia Social \\ Av. das Forças Armadas, 1649-026 Lisboa \\ luisa.lima@iscte.pt \\ Paulo silveira e sousa \\ Investigador no Centro de Investigação e Intervenção Social \\ Mestre em Ciências Sociais \\ Av. das Forças Armadas, 1649-026 Lisboa \\ paulo.sousa@eui.eu
}

Paula castro Professora Associada no ISCTE e Investigadora no Centro de Investigação e Intervenção Social Doutor em Psicologia Social Av. das Forças Armadas, 1649-026 Lisboa paula.castro@iscte.pt

* Artigo recebido em: 26/02/2009. Autores convidados. 
RESUMO A epidemia de gripe pneumónica ocorreu em Portugal num momento em que o país enfrentava enormes dificuldades de natureza económica, política e sanitária. Chega a um país rural e pobre, envolvido na Grande Guerra de 1914-18, e que se debate com a carência de géneros e a carestia de vida, e com uma fortíssima crise social e política. Apesar de o país estar habituado a sucessivas epidemias, o carácter imprevisto e violento da pneumónica (estima-se que tenha provocado quase 140 mil mortos num país com cerca de 6 milhões de habitantes) fez com que a resposta dos agentes políticos e sanitários fosse marcada por factores ligados à conjuntura (crise económica, social e política) e de tipo estrutural (condições higiénicas e sanitárias deficientes, falta de meios em capital económico, de médicos e de medicamentos, impotência do conhecimento médico para debelar a epidemia).

Palavras-chave Gripe pneumónica, autoridades de saúde pública, agentes políticos, Portugal

ABSTRACT The Spanish influenza epidemic occurred in Portugal when this country faced enormous economic, political and sanitary problems. The country was poor, living mainly from agriculture and was involved in the First World War. There were food shortages, a high cost of living, as well as a strong social and political crisis. Although people were used to deal with successive epidemic diseases, the sudden and violent character of the Spanish influenza took everybody by surprise. According to some estimation it killed about 140 thousand in a 6 million person's country. The answer of the political and sanitary agents was marked by contextual factors (the economic, social and political crisis) as well as by structural ones (very poor hygienic and sanitary conditions, lack of financial resources, of doctors and medicines, impotence of medical knowledge in dealing with the pandemic).

Keywords Spanish influenza, public health officers, political agents, Portugal

\section{Introdução}

Nas primeiras décadas do século XX, apesar da sociedade portuguesa atravessar um processo de transformação marcado pelo crescimento da população, pela industrialização e pelo desenvolvimento urbano, o país continuava a ser maioritariamente rural. No início da década em que tem lugar o surto epidémico conhecido internacionalmente como "influenza espanhola", quase $80 \%$ da população estaria ligada à agricultura, mesmo que esporadicamente exercessem outra ocupação, em actividade fabril ou artesanal: eram na sua esmagadora maioria pequeníssimos proprietários 
camponeses e proletários rurais pobres. ${ }^{1}$ A emigração era a via mais seguida pelos que procuravam fugir à pobreza. Entre 1900 e 1918 emigram cerca de 670.000 pessoas, a maioria para o Brasil, ${ }^{2}$ uma enorme proporção se tivermos em conta que a população de Portugal era em 1920, ano do censo mais próximo da pandemia, de 6.032.991 habitantes. ${ }^{3}$ Destes só 676.107 viviam nas cidades de Lisboa e Porto, as maiores do país, enquanto 4.929.365 viviam nas chamadas zonas rurais (em que se incluíam as cidades de pequena dimensão). ${ }^{4}$

Se quisermos reconstituir com rigor o contexto de ocorrência da epidemia e as reacções que esta suscitou, teremos de acrescentar a estes dados brevíssimos relativos à estrutura económica e social, alguns outros elementos, mesmo que sumários, relativos aos campos político, ideológico e da saúde e assistência. A instauração de um regime republicano em 1910 através de uma revolução alienara uma parte da população que se identificava com a monarquia. Além disso, a separação radical levada a cabo entre o estado e a igreja, seguindo os moldes da $3^{\text {a }}$ República Francesa, afrontou os meios católicos. De facto, ao procurar impor uma cultura oficial laica, de inspiração positivista, ao separá-la do estado, ao retirar à Igreja meios e influência (como os relativos ao registo civil), ao submeter a actividade religiosa e de corporações de inspiração religiosa (como as misericórdias) a um controlo estreito, ao expropriar-lhe propriedade, o novo regime afrontou esta instituição, especialmente forte nas áreas rurais do norte e do centro do país (as mais populosas). Entretanto, o regime republicano, que havia sido acolhido com toda a simpatia pelo universo operário maioritariamente urbano, reagiu, frequentemente com dureza, a movimentos sociais grevistas. Criaram-se assim focos de descontentamento contra os partidos mais influentes da república, em particular o mais importante, o Partido Democrático. A participação na I Grande Guerra ao lado dos aliados, em cuja promoção este partido teve papel destacado, feita sob a invocação da necessidade de protecção do império colonial português ${ }^{5}$ dividiu ainda mais os portugueses. Estes não eram confrontados há cerca de quase um século - desde os tempos das guerras civis da primeira metade de oitocentos - com uma mobilização militar de massas. E, em vários meios sociais, em especial entre os monárquicos, era notória a simpatia pela causa dos impérios contra os quais Portugal combatia.

As circunstâncias da guerra agravaram também situações de fome, carência alimentar e de carestia de vida e os conflitos sociais - com assaltos

OLIVEIRA MARQUES, A.H. de. História da $1^{a}$ República Portuguesa: as estruturas de base. Lisboa: Iniciativas Editoriais, 1978, p.309-311.

2 OLIVEIRA MARQUES, A.H. de. História da $1^{a}$ República Portuguesa, p.32-37.

3 Censo da população de Portugal de 1920. Lisboa: Imprensa Nacional, p.262-263.

4 SAMPAIO, Arnaldo. Subsídios para o estudo da epidemiologia da gripe. Lisboa: 1958, p.127.

5 Angola e Moçambique possuíam fronteiras com colónias alemãs e britânicas e receava-se a sua partilha entre estas potências beligerantes. 
a armazéns e estabelecimentos de artigos de primeira necessidade, em maio de 1917 - e políticos agudizaram-se. Em 1917, o golpe militar de 5 de dezembro, liderado por um militar republicano conservador, Sidónio País, inicia uma tentativa de mudança de regime a que o seu assassinato pôs cobro no ano seguinte. Este golpe, que acabou com um governo de uma coligação partidária dominada pelo Partido Democrático, que promovera a intervenção na Grande Guerra, pôs momentaneamente fim à hegemonia desse partido. Em seu lugar, instala-se um regime presidencialista cada vez mais autoritário, apoiado por republicanos conservadores, católicos, pela aristocracia, pela alta burguesia e por fracções abastadas da classe média urbana e rural e do campesinato proprietário. A construção deste bloco foi facilitada pelas expectativas, de tipo messiânico ou quase, colocadas na intervenção autoritária deste líder, e que ele e os seus cultivaram e na aproximação entre o presidente e a Igreja Católica, com a qual o novo regime restabeleceu relações. ${ }^{6}$

A epidemia de "gripe pneumónica", ou simplesmente "pneumónica", a designação mais vulgarizada da "influenza espanhola" em Portugal, vem portanto ocorrer neste contexto sócio-económico, político e ideológico específico.

\section{A saúde e a assistência em Portugal no tempo da "pneumónica"}

Com a entrada de Portugal na guerra em 1916 e o agravamento das condições de vida da população, a sua situação sanitária deteriorou-se. Já antes da epidemia havia uma mortalidade elevada no seio da população portuguesa. As autoridades sanitárias nacionais encarregadas da luta antituberculosa, a maior causa de mortalidade no Portugal da época, atribuíam à crise da habitação, défice de fogos e má qualidade do alojamento existente uma grave responsabilidade nos altos níveis de mortalidade registados por esta doença em Lisboa, por exemplo, onde, como no Porto, estes eram o triplo da percentagem nacional. ${ }^{7}$ Em 1905, o médico Augusto da Silva Carvalho adicionava a este factor a má e escassa alimentação das classes mais pobres. O pão em Portugal era caro, o peixe e o açúcar onerados com impostos e taxas alfandegárias elevadas, a carne também tinha um preço alto, bem como a manteiga. ${ }^{8} \mathrm{O}$ português de meios modestos não só vivia mal alojado, como também comia pouco e mal. Esta situação estrutural foi agravada pela conjuntura da guerra. Num breve espaço de tempo surgiram

6 FERREIRA, David. Sidónio Pais. In: SERRÃO, Joel. (coord.) Dicionário de História de Portugal. Porto: Livraria Figueirinhas, 1992, v.4, p.517-524.

7 A luta contra a tuberculose e a obra da assistência nacional aos tuberculosos, 1899-1928. Lisboa: Tip. Adolfo de Mendonça, 1928, p.13-14. Ver OLIVEIRA MARQUES, A.H. de. História da $1^{a}$ República Portuguesa: as estruturas de base, p.9.

8 CARVALHO, Augusto da Silva. Acção do saneamento geral sobre a tuberculose. Relatório apresentado ao $2^{\circ}$ Colóquio da Liga Nacional Contra a Tuberculose. Coimbra: Imprensa da Universidade, 1905, p.24-26. 
recorrentes surtos epidémicos. Estes últimos tomariam uma enorme amplitude e incidência durante o ano de 1918, que assistiu, além da pneumónica, a surtos epidémicos de varíola, febre tifóide, tifo enxatemático e disenteria. ${ }^{9}$

Como lembrou a mais importante autoridade sanitária portuguesa, director-geral da saúde e comissário geral do governo para dirigir o combate à epidemia, ${ }^{10}$ o professor Ricardo Jorge, a epidemia ocorria num tempo de escassez generalizada: de alimentos, de medicamentos, de transportes e de médicos. ${ }^{11}$

O conjunto de instituições da área da saúde e assistência no Portugal de início do século XX, conquanto já submetido a uma direcção centralizada sob a tutela do estado, estava ainda muito longe de corresponder à universalização de cuidados que viria a ser característica dos modernos serviços sociais e de saúde do estado-providência. ${ }^{12}$ Acompanhando o desenvolvimento mais global do aparelho de estado desde a $2^{\mathrm{a}}$ metade do século XIX, os serviços dependentes do estado começaram a complementar as antigas redes de assistência, tradicionalmente assentes em corporações religiosas, com particular destaque para as misericórdias, que se haviam desenvolvido a partir século XVI e que estavam dispersas pelo país, em instituições filantrópicas e múltiplas associações de socorros mútuos instituídas em oitocentos. A partir de então aparecem hospitais civis especializados, como o do Rego, para doenças infecto-contagiosas, o Real Hospital de Crianças (1882), ambos em Lisboa, sanatórios para a luta contra a tuberculose (1901) ou a primeira maternidade (em Lisboa, em 1911). Ao mesmo tempo, alarga-se a intervenção sobre a mendicidade e a infância e começam a construir-se as primeiras redes de controlo sanitário. ${ }^{13}$ A um outro nível, desde finais do século XIX, desenvolviam-se esforços para profissionalizar os serviços de enfermagem, juntando-se a

9 OLIVEIRA MARQUES, A.H. de. História da $1^{a}$ República Portuguesa, p.10-12.

10 ALVES, A. Lobo. Relatório do director geral dos Hospitais Civis. In: Hospitais civis de Lisboa, Repartição do boletim e serviços de estatística clínica, relatórios e notícias sobre a epidemia de gripe pneumónica. Lisboa: Imprensa Nacional, 1920 , p.7.

11 JORGE, Ricardo. La grippe. Lisbonne: Imprimerie Nationale, 1919, p.35.

12 A preocupação com a saúde pública emerge internacionalmente ao longo do século XIX, ligada à percepção da influência do ambiente - pobreza, falta de higiene...- na doença e nas epidemias em particular. Cf. PORTER, Dorothy. Public Health. In: BYNUM W.F. e PORTER Roy. (orgs.) Companion Encyclopedia of the History of Medicine. London \& New York: Routledge, 1993, v.2, p.1231-1261. Note-se, a título comparativo, que no Reino Unido só foi criado um Ministério da Saúde em 1919 no contexto específico do pós-guerra, marcado pela pobreza, pela doença e pelo desemprego. CF. PORTER, Roy. The greatest benefit of mankind. London: Fontana, 1999, p.642. Em Portugal seria criado em 1958, quase 40 anos depois. CAMPOS, António Correia de. Saúde Pública. In: BARRETO António e MÓNICA Maria Filomena. (coords.) Dicionário de História de Portugal. Porto: Livraria Figueirinhas, v.IX, 2000.

13 Ver NETO, Maria de Lurdes Akola. Assistência pública. In: SERRÃO, Joel. (coord.) Dicionário de História de Portugal, v..1, p.234-236. Ainda em termos comparativos, atente-se que o Serviço Nacional de Saúde Britânico, peça essencial do Estado-Providência, só viria a aparecer em 1948, e em Portugal seria nas décadas de 60 e 70 que o envolvimento do Estado viria a crescer. CAMPOS, António Correia de. Saúde pública. In: SERRÃO, Joel; BARRETO, António e MÓNICA, Maria Filomena. (coords.) Dicionário de História de Portugal. Ver para uma perspectiva comparada em vários países do papel do Estado em matéria de saúde, em que se assinala que as suas actividades tinham ainda um carácter ad-hoc em inícios do século XX, estando a saúde da maioria, como em Portugal, a cargo de associações voluntárias religiosas ou não, PORTER, Roy. The greatest benefit to mankind: a medical history of humanity, p.628-667. 
colaboração destes profissionais à dos médicos que se formavam em três escolas, no Porto, Lisboa e Coimbra. Em setembro de 1901 seria por fim criada e organizada uma Escola de Enfermeiros em Portugal, depois de algumas tentativas anteriores. ${ }^{14}$

Segundo os dados de 1915, parcialmente publicados em 1919, só no que respeitava à assistência hospitalar do continente, 63 \% dos doentes tratados no referido ano de 1915 foram-no por estabelecimentos de assistência privada, que possuíam então 70 \% do total dos leitos em serviço nos hospitais. Dos 251 hospitais portugueses, 241, ou seja $96 \%$, estava a cargo de instituições daquela natureza, na esmagadora maioria dos casos Santas Casas da Misericórdia. O principal hospital do Porto, a segunda cidade do país, utilizado para o ensino da medicina, pertencia à misericórdia local. ${ }^{15}$ Os estabelecimentos modernos e de carácter laico - como o importante Instituto Bacteriológico - concentravam-se em Lisboa, onde se operara uma centralização da organização hospitalar, com a instituição dos Hospitais Civis de Lisboa (1913).

Fora de Lisboa, e, em grau menor, do Porto e de Coimbra, onde havia para lidar com a saúde pública faculdades de medicina com hospitais anexos, nas sedes de distrito - a maior das unidades político-administrativas em que se subdividia o país - havia delegados de saúde (a quem cabia o cuidado da saúde pública e nomeadamente das doenças infecto-contagiosas e que reportavam ao director geral em Lisboa), e nos municípios (ou concelhos) havia subdelegados de saúde na dependência dos anteriores, bem como médicos municipais (muitos deles acumulavam o cargo com o de subdelegados). Além dos médicos, eram autoridades sanitárias os governadores civis dos distritos e os administradores do concelho nos municípios (ambas figuras de nomeação governamental. Ver Quadro 1 para uma clarificação da organização hierárquica das estruturas do estado português relevantes em questões sanitárias).

\section{Quadro 1. Estruturas hierárquicas do Estado Português em matéria sanitária em 1918}

\begin{tabular}{|l|l|l|}
\hline Nível & Autoridades Políticas & Autoridades de Saúde \\
\hline Nacional & Presidente da República, governo & Director geral da saúde \\
Distrital & Governador civil & Delegado de saúde \\
Municipal & $\begin{array}{l}\text { Administrador do concelho/câmaras } \\
\text { municipais }\end{array}$ & $\begin{array}{l}\text { Subdelegado de saúde/médico } \\
\text { municipal }\end{array}$ \\
\hline
\end{tabular}

14 Decreto de 10/09/1901. Ver também ALVES, Augusto Lobo. O Ensino de Enfermagem nos Hospitais de Lisboa. Discurso proferido na abertura da Escola Profissional de Enfermagem dos Hospitais Civis de Lisboa a 5 de Fevereiro de 1919. Separata de A Medicina Contemporânea, Lisboa: Tip. Adolfo de Mendonça, 1919.

15 AZEVEDO, António de. Actualidades. Assistência em Portugal. Medicina Contemporânea, n.4, p.31-32, 26/01/1919. NB: Já antes de 1911 se fez inquérito análogo ao que se encontra em conclusão em A Medicina Contemporânea, n. `9, 1910. Relatório da $2^{2}$ repartição da Direcção-geral de Assistência, no Diário do Governo, II série, n.10, p.124, 13/01/1919. 
Em teoria, os delegados de saúde deveriam ter um curso de especialização em Medicina Sanitária, mas a medida levaria décadas a tornar-se efectiva. Em muitos locais acumulavam este lugar com a prática da clínica privada, sendo ainda o seu consultório simultaneamente a sede da delegação local, sem mais meios que a letra da lei e uma caneta para escrever ofícios, pedidos e conselhos às restantes autoridades. ${ }^{16} \mathrm{Em}$ termos de princípios de assistência médica, na época e ainda depois, esta "mantinha-se caritativa para os pobres, e comercial, de clínica livre, para o resto da população". ${ }^{17}$ Ao estado competia a coordenação do conjunto de instituições do sector e assegurar "a luta contra as doenças evitáveis por meio de imunizações, polícia sanitária do comércio de alimentos, vigilância dos factores de risco do meio ambiente e, sob a forma de assistência pública na doença, uma protecção mínima a indigentes". ${ }^{18}$

Em 1920 havia em todo o país um efectivo de 2.580 médicos, o que dava um médico para cada 2.338 habitantes. Havia igualmente 1.577 farmácias, dando uma relação de 3.825 habitantes por cada uma. Mas estas médias são enganadoras, pois médicos e farmácias estavam concentrados nas cidades, sobretudo nas maiores, Lisboa e Porto. ${ }^{19}$ No mundo rural as carências eram enormes. Em 2.848 freguesias da província - a freguesia é a unidade político-administrativa mais pequena - , abrangendo uma população de 2.613.332 habitantes, não havia nem assistência médica nem farmácia. ${ }^{20}$

Se a Direcção Geral da Saúde Pública era o órgão de cúpula que dirigia e fiscalizava todos os outros serviços, na realidade, muitos melhoramentos na área da saúde e higiene públicas - recolha de lixos, saneamento... - continuavam dependentes da boa vontade e dos recursos escassíssimos das câmaras municipais, constantemente acusadas de pouco ou nada fazerem na matéria. Este tipo de comportamento era apenas alterado em períodos de surtos epidémicos, quando a escala da mortalidade pedia a intervenção dos especialistas. ${ }^{21}$

16 CORREIA, Fernando da Silva. Portugal sanitário (subsídios para o seu estudo). Lisboa: Ministério do Interior e da Saúde Pública, 1938, p.339-354.

17 CAMPOS, António Correia de. Saúde pública. In: Dicionário de História de Portugal, p.406.

18 CAMPOS, António Correia de. Saúde pública. In: Dicionário de História de Portugal, p.406; CAMPOS, António Correia de. Saúde, o custo de um valor sem preço. Lisboa: Editora Portuguesa de Livros Técnicos e Científicos, 1983. Estes objectivos eram comuns a outros Estados. Cf. FOX, Daniel M. Medical institutions and the state. In: BYNUM, W.F e PORTER, R. (orgs.) Companion Encyclopedia of the History of Medicine, v.2, p.1204-1230.

19 CORREIA, Fernando da Silva. Problemas de higiene e puericultura. Coimbra: Imprensa da Universidade, 1934, p.229-230. No Algarve (que em termos político-administrativos era o distrito de Faro), havia 34 médicos para perto de 270.000 habitantes, o que dá uma média de um médico para cerca de 7.900 indivíduos. Ainda assim, concentravam-se na capital, com 6 e pouco menos de 25.000 residentes. Ver GIRÃO, Paulo. A pneumónica no Algarve. Casal de Cambra: Caleidoscópio, 2003, p.30-31, 102-103.

20 Veja-se por exemplo a comunicação apresentada ao Congresso Nacional de Medicina de Lisboa em 1928 por Fernando da Silva Correia e republicada na colectânea de textos do mesmo autor CORREIA, Fernando da Silva. Problemas de higiene e puericultura, p.219-274

21 Mesmo referindo-se a um período posterior veja-se CORREIA, Fernando da Silva. A centralização dos serviços de higiene. Separata de A medicina contemporânea, n.3, 17/04/1932. 
Na década em que ocorre o surto da pneumónica, e em particular com o impacto das descobertas da bacteriologia, havia uma consciência forte da importância das medidas de higiene, de salubridade e de profilaxia de carácter básico para evitar o surgimento e propagação de epidemias ${ }^{22}$ que também são acolhidas em Portugal. Porém, as consequências políticas e o impacto em termos de medidas concretas seriam, por enquanto, muito limitados. A construção de infra-estruturas e de equipamentos de distribuição de água e de esgotos, a melhoria das condições de habitabilidade e o desenvolvimento da salubridade urbana, bem como a criação de serviços de prevenção e de fiscalização pouco se terá desenvolvido e, quando ocorreu, limitou-se a Lisboa, Porto e uma ou outra capital de distrito. ${ }^{23}$ Do lado da saúde pública e da profilaxia o retrato não era melhor. Processos como a divulgação dos princípios de higiene pessoal entre a população, ou a organização em redes acessíveis e coordenadas dos serviços médicos e de enfermagem, com capacidade para o diagnóstico e o tratamento precoce da doença, eram realidades circunscritas ao discurso dos médicos e de alguns funcionários públicos. Neste cenário, doenças como o paludismo (ou malária), a febre tifóide, o tifo exantemático, o carbúnculo, a varíola e a difteria eram comuns. A tuberculose continuaria a ceifar a vida de milhares de adultos jovens nas principais áreas urbanas, sobretudo entre a população mais pobre, mal alojada e pior alimentada - e só em 1918, a mortalidade que ela provocava foi excedida pela "pneumónica". ${ }^{24} \mathrm{~A}$ epidemia de gripe de 1918-19 ocorre num contexto marcado por epidemias múltiplas e recorrentes. Uns vinte anos depois, e este é um indicador importante em termos comparativos, Portugal era ainda o país da Europa em que a mortalidade por varíola, difteria e tifo exantemático era mais alta. ${ }^{25}$ Embora a gripe não fosse uma desconhecida, pois entre 1902 e 1910 ocupou o 5. lugar no quadro da mortalidade por doenças contagiosas, as formas de que se revestiu o surto de 1918-19 tiveram um carácter violento e imprevisível. ${ }^{26}$ Em Portugal como no resto do mundo.

\section{Medidas de combate às epidemias}

Apesar do recurso crescente a todo um novo arsenal teórico e prático, nomeadamente o decorrente das descobertas da bacteriologia e em geral

\footnotetext{
22 VIGARELLO, Georges. Histoire des pratiques de santé: le sain et le malsain depuis le Moyen Âge. Paris: Éditions du Seuil, 1999, p.240-243, 260-265. KOLATA, Gina. Flu: the story of the great influenza pandemic of 1918 and the search for the virus that caused it! New York: Touchstone, 2005, p.47.

23 CORREIA, Fernando da Silva. Portugal sanitário, p.499-507.

24 CORREIA, Fernando da Silva. Portugal sanitário, p.197.

25 CORREIA, Fernando da Silva. Portugal sanitário, p.192.

26 CORREIA, Fernando da Silva. Portugal sanitário, p.233.
} 
da "medicina de laboratório" em finais do século anterior, ${ }^{27}$ muitas das epidemias continuavam a ser combatidas através dos velhos esquemas. Se havia a percepção da necessidade de promover medidas de prevenção e de incremento da salubridade, notoriamente desde o século XIX, ${ }^{28} \mathrm{O}$ facto é que a actuação dos médicos e das redes de polícia sanitária e de prestação de cuidados se caracterizava por uma atitude passiva ou menos reactiva face à doença, actuando-se, muitas vezes, somente após a sua manifestação. Se agora se recorria às pesquisas nos laboratórios para os diagnósticos, o facto é que, no tratamento, se continuavam a aplicar as clássicas medidas de quarentena. Logo que se desencadeavam os surtos a máquina administrativa era posta em funcionamento sob o comando de médicos especialistas. As cartas de saúde tornavam-se obrigatórias, sendo necessários os respectivos vistos, visitas de saúde, inspecções e se necessário impedimentos de comunicação e desinfecções coercivas. ${ }^{29}$

O Instituto Central de Higiene, inspirado em modelos alemães, fundado em Lisboa em 1899 pelo higienista e epidemiologista Ricardo Jorge, no contexto do combate à epidemia de peste bubónica deflagrada na cidade do Porto no mesmo ano, procurava desenvolver o estudo da higiene e da salubridade pública, a estatística das epidemias e formas de vigilância epidemiológica. ${ }^{30}$ Tentava-se, assim, esclarecer o obituário, implementar a notificação obrigatória de doenças perigosas, registar eventuais surtos epidémicos, acompanhar a evolução das principais causas de mortalidade, procedendo ainda ao estudo monográfico de algumas moléstias infecciosas, como seria o caso conhecido da malária. Neste instituto ministravase o curso de Medicina Sanitária - e o de Engenharia Sanitária - onde se ensinavam higiene pública, controle de factores de risco (como os ligados à alimentação e à habitação), assistência às classes pobres e práticas de combate às epidemias e de profilaxia, por exemplo. ${ }^{31}$ À época, como se

27 PORTER, Roy. The greatest benefit to mankind: a medical history of humanity, p.428; PORTER, Roy. Blood \& guts: a short history of medicine. London: Penguin, 2002, p.75-98; SOURIA, Jean-Charles. Histoire de la médicine. Paris: La Découverte, 2007, p.222-254; UJVARI, Stefan Cunha. A História e suas epidemias: a convivência do homem com os microorganismos. Rio de Janeiro/São Paulo: Editora Senac, 2003, p.157-229. Eram objectivos comuns a outros Estados. Em Portugal, a bacteriologia era ensinada desde a última década do século XIX. CORREIA, Fernando da Silva. Portugal sanitário, p.443.

28 CORREIA, Fernando da Silva. Portugal sanitário, p.499-507.

29 Ver por exemplo ENES, Guilherme José. Processos e progressos da desinfecção pública em Lisboa. Lisboa: Liv. de José António Rodrigues, 1901 e a obra de FREIRE, António Jorge. Plano geral de defesa permanente contra a difusão e invasão das doenças infecciosas. Lisboa: 1890.

30 Ricardo Jorge foi a principal figura da epidemiologia portuguesa e um contemporâneo da ascensão dos epidemiologistas no plano médico internacional. Com a sua obra Higiene social aplicada à nação portuguesa (1884) estabeleceu os alicerces da saúde pública em Portugal. Foi director-geral da saúde em três regimes políticos distintos - monarquia, república (1910-1926), ditadura militar (1926-1929), continuando, depois de aposentado, a exercer grande influência. Quando se aposentou, o Instituto Central de Higiene veio posterior a ser chamado Instituto Nacional de Saúde Dr. Ricardo Jorge. Ver: CORREIA, Fernando da Silva. O Instituto Superior de Higiene Dr. Ricardo Jorge. Separata do Boletim de Assistência Social, Lisboa, v.15, p.53-76, 1957; FERNANDES, Henrique Joäo Barahona. Ricardo Jorge. Separata do Jornal da Sociedade de Ciências Médicas, Lisboa, v.123, 1959.

31 GRAÇA, Luis. História da saúde no trabalho: a reforma da saúde pública no virar do século XIX. Lisboa: 2000. In: http://www.ensp.unl.pt/Igraca/textos16.html\#3.\%20Limites\%20da\%20reforma\%20da\%20saúde\%20de\%201901. (Acedido a 9/02/2009). 
constata, e se sublinha, a doença era entendida tanto em termos biológicos como sociais. ${ }^{32}$ Havia, portanto, já um importante corpus de reflexão e de conhecimento, e instituições específicas de combate às epidemias desde os fins do século XIX, - mais dois cursos de higiene para ensinar saúde pública seriam criados em Coimbra e no Porto na primeira década do século XX - quando o ensino da higiene e o ensino e a investigação bacteriológica se difundem em Portugal. Mas o país não era só Lisboa e os limites da inovação nestas matérias eram ainda flagrantes 20 anos depois da epidemia de gripe. ${ }^{33}$

\section{O surto de "pneumónica" de 1918-1919}

A gripe pneumónica revestiu-se em Portugal de características similares e de uma temporalidade análoga à registada a nível mundial. ${ }^{34}$ Desenrolouse, igualmente, em três vagas. A primeira terá penetrado em Portugal com os trabalhadores agrícolas regressados de Espanha onde esta já se havia declarado. ${ }^{35}$ Afectando as cidades de Lisboa e Porto, teve o seu ponto culminante no final do mês de junho de 1918, declinando depois subitamente. Se bem que fugaz e relativamente benigna, ela faria, mesmo assim, subir a mortalidade geral citadina, tal como sucedera no surto de gripe 1896. ${ }^{36}$ A segunda vaga começou por se manifestar na zona do Porto (Gaia), no norte do país, em agosto e daí irradiou imediatamente para o noroeste e por ambas as margens do vale do Douro até à fronteira de Espanha, havendo outros focos no centro do país; o litoral, o centro e o sul estavam ainda indemnes em meados de setembro, mas nos começos de outubro atingia o Algarve, a província situada no extremo sul do país. ${ }^{37}$

Este surto teria uma incidência bem maior junto da população, sendo a mortalidade e virulência superiores a quaisquer outras graves epidemias registadas anteriormente, como por exemplo as de febre-amarela (1856) e cólera (1857) ocorridas em Lisboa e sem qualquer comparação com surtos anteriores de influenza, como o de $1889-1890 .{ }^{38}$ Ocorreria ainda uma terceira

32 PORTER, Roy. The greatest benefit to mankind, p.634

33 CORREIA, Fernando da Silva. Portugal sanitário, p.433-446.

34 PHILLIPS, Howard \& KILLINGRAY, David. Introduction. In: PHILLIPS, Howard \& KILLINGRAY, David. (eds.) The Spanish influenza pandemic of 1918-19: new perspectives. London and New York: Routledge, 2003, p.5-7.

35 JORGE, Ricardo. La grippe, p.7.

36 Referências ao seu carácter benigno, embora colocando reservas, encontram-se em JORGE, Ricardo. La Grippe, p.8. A mesma opinião sobre os Estados Unidos em CROSBY, Alfred. America's forgotten pandemic: the influenza of 1918. Cambridge: Cambridge University Press, 2003, p.17. Sobre a $1^{\mathrm{a}}$ vaga em Espanha refere-se a também a sua relativa moderação em ECHEVERRI DÁVILA, Beatriz. La gripe española: la pandemia de 1918-19. Madrid: CIS/Siglo XXI de España Editores, 1993, p.27. É a opinião que recolhe PORTER, Roy. The greatest benefit of mankind, p.483

37 JORGE, Ricardo. La grippe, p.14-15. Na sua comunicação ao Conselho Superior de Higiene, em finais de Setembro, R. Jorge já afirma, antes da sua plena eclosão, que a segunda vaga de "influenza pneumónica" seria mais perigosa que a primeira. In: O Século, 25-9-1918

38 JORGE, Ricardo. La grippe, p.15. 
vaga, em abril e maio de 1919, ${ }^{39}$ mas já sem as características especialmente mortíferas da anterior. Os fluxos da população - cuja importância a nível mundial na propagação desta epidemia foi destacada ${ }^{40}$ - foram apontados como responsáveis pelo contágio entre as diversas regiões do país: a "migração militar", ligada à deslocação das tropas num país em guerra; a agrícola, devido à deslocação em grandes efectivos de trabalhadores para a colheita das uvas (vindimas), no Douro e no sul no mês de setembro; a "migração popular" ligada às feiras e às peregrinações que conhecem a sua maior intensidade em julho, agosto e setembro; a "migração balnear", com a deslocação e concentração de pessoas em praias e estâncias termais; a "migração marítima", devido aos transportes por mar, teria igualmente propiciado o contágio. ${ }^{41}$

Há uma grande incerteza quanto à mortalidade efectiva que a pandemia provocou, tanto a nível global como no caso português. Recentemente Killingray e Phillips, ${ }^{42}$ admitindo embora que a falta de dados e de fontes precisas fizesse com que tal número não passasse de uma estimativa informada, apontaram para o número de 30 milhões de mortes, muito mais do que as provocadas pela Grande Guerra. Este é o número indicado como mínimo por Crosby. ${ }^{43}$ Há quem refira mais de 25 milhões. ${ }^{44}$ Há quem fale numa estimativa entre 40 a 50 milhões, incluindo estimativas sobre populações, em particular na África e na Ásia, relativamente às quais não há dados fiáveis. ${ }^{45}$ Outros autores, também ainda há pouco, reviam os números em alta para 50 milhões de mortos à escala global, admitindo que o número pudesse subir para o dobro, dado o facto de haver défices de registo. Quanto a Portugal, referia-se uma mortalidade de 59.000 pessoas, com uma taxa de mortalidade de 9,8 (por 1.000), só ultrapassada na Europa pela Espanha, pela Itália - companheiras habituais de Portugal em outras epidemias - e pela Hungria e em marcado contraste com o norte da Europa (na Noruega e Suécia a taxa era de pouco mais de cinco por mil). ${ }^{46}$ De acordo com as estatísticas oficiais morreram 55.780 pessoas vitimadas pela gripe em 1918 (em 1919, 3.097) - recorde-se que o país tinha então em torno de 6.000.000 habitantes ${ }^{47} \mathrm{~A}$ taxa de mortalidade em Portugal seria superior à de países

39 JORGE, Ricardo. La grippe, p.18.

40 PORTER, Roy. The greatest benefit to mankind, p.483.

41 JORGE, Ricardo. La grippe, p.21-23. A ênfase colocada nos quartéis do exército como fonte de contágio, que aparece em múltiplos locais a nível internacional, também foi aqui constatada. Ver: JORGE, Ricardo. Influenza pneumónica. Portugal Médico, Porto, 3ª série, v.4, n.9, p.576, Setembro de 1918; GARRETT, Almeida. Contra a epidemia de gripe pneumónica, em 1918, no norte do país (relatório). Portugal Médico, Porto, n.11, p.663, 1919.

42 PHILLIPS, Howard e KILLINGRAY, David. (eds.) Introduction. In: The Spanish influenza pandemic of 1918-1919: new perspectives, p.4.

43 CROSBY, Alfred. America's forgotten pandemic, p.XII.

44 PORTER, Roy. The greatest benefit to mankind: a medical history of humanity, p.483

45 OLDSTONE, Michael B. A. Viruses, plagues and history. Oxford: Oxford University Press, 2000, p.173-175.

46 JOHNSON, Niall P. A. S. \& MUELLER, Juergen. Updating the accounts: global mortality of the 1918-1920 Spanish's influenza pandemic. Bulletin of History of Medicine, v.76, p.105-115, 2002.

47 CORREIA, Fernando da Silva. Portugal sanitário, p.479. Ver Estatística do movimento fisiológico da população de Portugal. Ano de 1918. Lisboa: Imprensa Nacional, 1922, p.110. 
como a Espanha e a Itália. ${ }^{48}$ Mas um autor afirmaria que o número de mortos por gripe poderia ter chegado a uma cifra um pouco superior aos 100.000 se acrescentássemos os casos dos que morreram em 1918 em excesso do habitual por infecções do aparelho respiratório e o acréscimo dos efectivos registados no mesmo ano por doença de causa não averiguada. ${ }^{49} \mathrm{Na}$ actualidade, o demógrafo Leston Bandeira estima que a gripe terá ocasionado, em 1918 e 1919, uma sobremortalidade de 135.257 óbitos. ${ }^{50}$ Para Espanha, país muito mais populoso, propôs-se recentemente um total de 257.082 mortes. ${ }^{51}$ Independentemente do número exacto, a brutalidade do evento é notória. Foi uma verdadeira hecatombe, responsável por uma forte ascensão da mortalidade em Portugal no quinquénio de 1916-1920,52 e que se revestiu de contornos humanos dramáticos.

A maior parte dos óbitos verifica-se nos meses de outubro e novembro, tal como sucedeu de um modo geral a nível internacional. Os grupos etários mais atingidos em termos de mortalidade em Portugal, tal como a nível mais global, foram os adultos jovens situados no intervalo entre os 20-40 anos, precisamente os que se pensariam estarem mais aptos a resistir, mas a razão de tal ainda não está cabalmente explicada..$^{53}$

Não possuímos uma imagem clara do impacto diferenciado da morbilidade e da mortalidade nas diferentes classes da sociedade, todas atingidas pela epidemia. ${ }^{54}$ Não parece haver consenso internacional a este respeito. Killingray e Phillips ${ }^{55}$ afirmaram que os pobres, os que viviam aglomerados em habitações insalubres, tinham em geral uma nutrição deficiente e uma saúde pobre em geral, foram os mais vulneráveis à doença, o que,

48 MACHADO, J. T. Montalvão. Como nascem e morrem os portugueses: estudo demográfico. Lisboa: Depositários Gomes \& Rodrigues, 1959, p.185.

49 CORREIA, Fernando da Silva. Portugal sanitário, p.479-480, p. 233

50 LESTON BANDEIRA, Mário. A sobremortalidade de 1918 em Portugal: uma análise demográfica. Comunicação apresentada no Colóquio internacional Olhares sobre a Pneumónica. Lisboa: Instituto de Ciências Sociais da Universidade de Lisboa, 15-16 de Novembro de 2007.

51 ECHEVERRI, Beatriz, Spanish influenza seen from Spain. In: PHILLIPS, Howard \& KILLINGRAY, David. (eds.) The Spanish influenza pandemic of 1918-19: new perspectives, p.173-190, em particular p.183.

52 MACHADO, J. T. Montalvão. Como nascem e morrem os portugueses: estudo demográfico, p.185.

53 JORGE, Ricardo. La grippe, p.25; ALVES, A. Lobo. Relatório do director geral dos Hospitais Civis. In: Relatórios e notícias sobre a epidemia de gripe pneumónica.; LESTON BANDEIRA, Mário. A sobremortalidade de 1918 em portugal: uma análise demográfica, p.13-14; GALLO, Isabel Porras. Un reto para la sociedad madrileña: la epidemia de gripe de 1918-19. Madrid: Editorial Complutense, 1997, p.65; ECHEVERRI DÁVILA, Beatriz. La gripe española: la pandemia de 1918-19, p.122-123; TAUTENBERG, Jeffrey K. \& MORENS, David M. 1918, influenza: the mother of all pandemics. Emerging infectious diseases [serial on the internet], v.12, n.1, p.15-22, em particular p.19, janeiro 2006; CROSBY, Alfred. America's forgotten pandemic, p.322; PHILLIPS, Howard e KILLINGRAY, David. (eds.) Introduction. In: The Spanish influenza pandemic of 1918-19: new perspectives, p.8-9; SILVEIRA. Anny Jackeline Torres. A influenza espanhola e a cidade planejada: Belo Horizonte, 1918. Belo Horizonte: Argumentum Editora, 2008, p.34

54 No conjunto do território de Portugal continental (isto é, sem os arquipélagos dos Açores e da Madeira), houve mais mulheres a morrer do que homens. Ver LESTON BANDEIRA, Mário. A sobremortalidade de 1918 em Portugal: uma análise demográfica, p.16. As razões ainda não foram investigadas. O facto dever-se-á, pelo menos em parte, ao papel de prestação de cuidados, nomeadamente a enfermos, por parte das mulheres?

55 PHILLIPS, Howard \& KILLINGRAY, David. (eds.) Introduction. In: The Spanish influenza pandemic of 1918-19, p.9. 
entre outros casos, Killingray também constatou para as Caraíbas. ${ }^{56}$ Para esta conclusão aponta, no caso espanhol, que interessa particularmente a Portugal, uma pesquisa de âmbito nacional que assevera que embora a gripe afectasse todas as classes sociais, o desenlace (maior ou menor mortalidade) não era o mesmo; localiza a diferença em ter-se ou não um corpo são e bem alimentado e acesso a práticas de higiene e cuidados elementares adequados. ${ }^{57}$ Mas há quem afirme, embora restringindo essa análise à cidade de Madrid, ser difícil falar, para a gripe, em mortalidade diferenciada entre distritos, embora tal sucedesse no caso da tuberculose. ${ }^{58}$ No Brasil Bertucci ${ }^{59}$ afirma sobre São Paulo serem os mais pobres quem mais sofria; Silveira cita aprovadoramente o estudo de Bertolli Filho sobre São Paulo que refere que a influenza nada teve de democrático, e a partir do seu estudo sobre Belo Horizonte reafirma ser "a visão democrática da epidemia uma ilusão", ${ }^{60}$ opinião que é partilhada em estudo sobre Salvador, Bahia. ${ }^{61}$ Opondo-se a esta correlação entre efeitos da epidemia e posição encontramos autores que defendem que a gripe ignorou as diferenças, nomeadamente as da classe; e admitem que, no máximo, os ricos tiveram uma ligeira vantagem e em muitos casos nem isso. ${ }^{62}$ Insiste-se em que ela agia de forma indiscriminada, atingindo os primeiro-ministros da Alemanha, França, Inglaterra, o presidente dos EUA, Woodrow Wilson ${ }^{63}$ e o presidente eleito do Brasil. ${ }^{64}$

Em Portugal não há propriamente consenso e nesta matéria será necessário proceder a investigação mais detalhada. Houve vítimas nas classes altas e nas fracções mais elevadas da classe média e no meio artístico, como o conde de Almeida Araújo, ${ }^{65}$ o neto do visconde de Alvalade, José Roquete, um dos fundadores do clube de futebol Sporting Clube de Portugal, os compositores Pedro Blanco e António Fragoso, os famosos pintores modernistas Amadeu de Sousa Cardoso e Santa Rita Pintor. A mais alta autoridade em matéria de epidemiologia e saúde pública, o director-geral da saúde, Ricardo Jorge, escreveu: "se todas as classes pagaram o seu tributo, ele pesou mais pesadamente sobre os mais humildes; os horrores da epidemia juntaram-se uma vez mais aos da miséria". ${ }^{66}$ Ele próprio nar-

56 KILLINGRAY, David. The influenza pandemic of 1918-19 in the British Caribbean. Social History of Medicine, v.7, p.59-87, 1994.

57 ECHEVERRI DÁVILA, Beatriz. La gripe española, p.103-170; ECHEVERRI DÁVILA, Beatriz. Spanish influenza seen from Spain. In: PHILLIPS, Howard \& KILLINGRAY, David. (eds.) The Spanish influenza pandemic of 1918-19: new perspectives.

58 GALLO, Isabel Porras. Un reto para la sociedad madrileña: la epidemia de gripe de 1918-19, p.57-60

59 BERTUCCI, Liane Maria. Influenza, a medicina enferma. Campinas: Editora da Unicamp, 2004, p.118-119.

60 SILVEIRA, Anny Jackeline Torres. A influenza espanhola e a cidade planejada, p.188-196.

61 SOUZA, Christiane Maria Cruz de. A gripe espanhola em Salvador, 1918: cidade de becos e cortiços. Revista História Ciências Saúde - Manguinhos, Rio de Janeiro, vol.12, n.1, p.71-99, jan-abr.2005.

62 CROSBY, Alfred. America's forgotten pandemic, p.323.

63 OLDSTONE, Michael B. A. Viruses, plagues and history, p.174-175.

64 BERTUCCI, Liane Maria. Influenza, a medicina enferma, p.352.

65 Cf. O Século, 2-10-1918.

66 JORGE, Ricardo. La grippe, p.25 
ra um facto em que a mortalidade surge estratificada por classe - classe social e classe no transporte - na viagem do vapor Moçambique entre a colónia portuguesa de Moçambique e Lisboa em setembro de 1918. Trazia 952 passageiros e a mortalidade geral foi de $22 \%$. Porém, a mortalidade de 558 soldados acumulados na $4^{\text {a }}$ classe foi de 180 indivíduos, mais de $30 \%$; na $3^{a}, 2^{a}$ e $1^{a}$ classes, onde viajavam 261 oficiais, sargentos e civis, morreram apenas $7,2 \%$. Nenhum oficial morreu. ${ }^{67} \mathrm{Um}$ médico, leitor do The Lancet, a quem o surto, que combateu, apanhou em férias de Verão numa zona rural e industrial do norte de Portugal, o vale do Ave, escreveu o que podemos designar como uma pequena etnografia da epidemia. Tratou mais de meio milhar de doentes, achando que as manifestações mais graves da epidemia se deram entre os que tinham piores condições de vida em matéria de habitação. ${ }^{68}$

Posição distinta à de Ricardo Jorge teve o seu subordinado Almeida Garrett, encarregado da direcção do combate à epidemia em finais de setembro (a $2^{a}$ vaga) em Vila Real, na região do Douro, onde ela grassava com particular intensidade, e que exerceu funções de superintendência sobre o norte do país. Referindo-se à incidência da segunda vaga na segunda cidade do país, o Porto, onde residia, ele afirma textualmente que "como eu, diversos colegas tiveram a impressão de não serem as classes pobres mais castigadas do que as ricas". ${ }^{69}$ Mas não vai além da impressão... Entretanto, uma análise demográfica muito recente concluiu que os efeitos mortíferos da pneumónica foram menores nas cidades do Porto e de Lisboa, do que em todos os outros distritos do continente, apontando para o facto de o combate à epidemia poder ter sido mais eficaz, onde havia uma maior presença dos serviços de saúde e maior eficácia dos controles administrativos. ${ }^{70} \mathrm{O}$ país rural, mais pobre, foi o que mais sofreu, por comparação.

O militante anarco-sindicalista Emídio Santana, particularmente atento ao sucedido com as classes trabalhadoras, escreveu sobre a epidemia e o contexto em que ela ocorreu:

Às calamidades económicas e políticas da época, com as polícias políticas levando para as prisões trabalhadores militantes ou revoltados, ao luto das famílias que perdiam os seus familiares na guerra lá longe, acresceram ainda as epidemias.

67 JORGE, Ricardo. La grippe, p.23-24.

68 LIMA, Joaquim A. Pires de. Notas sobre a epidemia gripal. Separata do Portugal Médico, Porto, $3^{a}$ série, v.IV, n.11, p.12, 1918. A respeito de uma epidemia de gripe dos anos 50 em Lisboa, dois especialistas do seu combate afirmam esta mais grave para os mais desfavorecidos. Consultar SAMPAIO, Arnaldo e CAEIRO, F.M. Contribuição para o estudo da epidemiologia da gripe através de um inquérito por amostra representativa da cidade de Lisboa. Boletim dos Serviços de Saúde Pública, v.V, n.3, p.383-491,1958.

69 GARRETT, Almeida. Contra a epidemia de gripe pneumónica, em 1918, no norte do país, p.653-73.

70 LESTON BANDEIRA, Mário. A sobremortalidade de 1918 em Portugal: uma análise demográfica, p.6-7. Em sentido que se afigura no geral concordante, ver ECHEVERRI DÁVILA, Beatriz. La gripe española: la Pandemia de 1918-19, p.170. 
No final de 1918 "a pneumónica" grassava intensamente criando um estado de pânico colectivo.

Era frequente ver-se nas ruas grupos de pessoas consternadas que comentavam a morte recente deste ou daquele vizinho, e os funerais às vezes sucediam-se, a caminho dos cemitérios. Como as carretas funerárias não acudiam a tantos funerais, algumas vezes se via os caixões serem transportados "a pau e corda", vulgar meio de transporte de mobílias ou mercadorias, pelos chamados moços de fretes, e que consistia num tabuleiro de madeira suspenso por duas cordas e duas varas grossas que se apoiavam nos ombros de quatro homens, acompanhados do préstito fúnebre. ${ }^{71}$

\section{A resposta das autoridades de saúde pública}

Segundo uma nota publicada nos jornais em 28 maio de 1918, o director-geral da saúde pública, Ricardo Jorge, comunicou ao Conselho Superior de Higiene que a doença tinha alastrado rapidamente por toda a Espanha. A difusão "quase explosiva" por toda a parte e por todas as classes (chegando a atacar um terço da população), era tida, contudo, como própria da "influenza". ${ }^{72}$ Reiterou o diagnóstico de influenza ou gripe, causada por um vírus, em relatório apresentado ao mesmo Conselho Central de Higiene em 18 de Junho. Referiu-se aí a sua extrema contagiosidade e apontou-se para o facto do seu carácter benigno ser apenas aparente, pois se tratava de uma epidemia mortífera. Apesar de se reconhecer a ineficácia do isolamento perante a propagação do vírus, não deixava de se recomendar $\mathrm{o}$ isolamento dos atingidos pela epidemia e outras medidas para evitar o contágio, desde deixar de visitar doentes a cumprimentar pessoas com as mãos ou dar beijos. Não haveria práticas imunizantes, nem drogas preventivas. Recomendava: lavar as vias respiratórias com água salgada ou água oxigenada diluída; manter a higiene interna e externa; tomar ar livre e ventilar habitações. E, por fim, quando alguém era atacado pelo mal, "cama, dieta, tizanas e médico". ${ }^{73}$ A 31 de agosto divulgava na Imprensa tratar-se de "influenza pneumónica". ${ }^{74}$

Durante o verão as autoridades sanitárias pouco terão actuado. Mas a situação iria mudar diante das características da $2^{a}$ vaga da gripe. A 29 de setembro o director-geral da saúde pública fazia sair as primeiras instruções oficiais que explicitamente pretendiam coordenar o combate à epidemia. A2

71 SANTANA, Emídio. Memórias de um militante anarco-sindicalista: tempos de luta de adversidade e de esperança. Lisboa: Perspectivas \& Realidades, 1987, p.33.

72 A epidemia de Hespanha. Medicina Contemporânea, n.22, p.176, 02/06/1918. Autor desconhecido.

73 JORGE, Ricardo. A nova incursão peninsular da influenza. Portugal médico, Porto, $3^{a}$ série, v.IV, n.6, p.436-443, junho de 1918. Eram também as medidas preconizadas, após muito debate em torno da influenza, pelo Royal College of Physicians do Reino Unido. LOEB, Lori. Beating the flu: orthodox and commercial responses to the influenza in Britain, 1889-1919. Social History of Medicine, v.18, n.2, p.203-224, 2005.

74 Portugal Médico, n.8. 
de outubro elas eram transformadas em portaria da Secretaria de Estado do Trabalho publicada a 4 de outubro no Diário do Governo. ${ }^{75}$ As instruções dividiam-se em seis pontos e iam recomendadas às autoridades sanitárias.

O primeiro ponto tentaria construir um sistema de recolha de informação e determinava que todos os médicos deveriam participar às subdelegações de saúde respectivas a aparição na sua clínica de casos epidémicos de gripe. O subdelegado, ou um seu representante, deveria depois transmitir telegraficamente a súmula destes dados à delegação competente, que os enviaria pela mesma via à Direcção Geral da Saúde Pública, prestando as informações necessárias para que se pudessem avaliar a extensão e intensidade da epidemia.

O segundo ponto dizia que não havia "profilaxia específica contra o contágio", mas que subsistiam "as normas da higiene geral - a beneficiação e a desinfecção". A limpeza das povoações e das casas deveria, por isso, continuar a merecer cuidados. Perante o pouco conhecimento da etiologia e das formas de contágio continuava-se a aconselhar a desinfecção, o isolamento, devendo evitar-se, se possível, aglomerações e contactos. Como profilaxia individual, não deixa de se lembrar o uso de gargarejos, "mentolados ou salgados". Num segundo parágrafo deste ponto o director-geral da saúde pública tentaria chamar a atenção das autoridades em relação às movimentações de populações, para as evitar e vigiar.

O terceiro ponto procurava organizar os hospitais e dizia que para os casos graves estava indicada a hospitalização, com tratamento e isolamento, a arma mais eficaz contra a epidemia. Devia-se aproveitar os hospitais existentes e improvisá-los, requisitando prédios onde não os houvesse, bem como camas e roupas. Devia obter-se a colaboração das corporações locais. Onde não existissem bombeiros e Cruz Vermelha para o transporte de doentes, a autoridade administrativa devia providenciá-los.

Em quarto lugar pedia-se que se organizassem e utilizassem todos os médicos disponíveis, incluindo os militares e os aposentados ainda em estado de servir.

A quinta instrução pretendia estabelecer regras para a boa organização territorial das estruturas médicas e farmacêuticas. A área dos concelhos (municípios) deveria ser dividida em zonas, correspondendo a cada uma, para assistência dos mais pobres -em quem normalmente se pensava como mais atreitos ao contágio - um médico e uma farmácia. As receitas passadas aos mais necessitados eram gratuitas, ficando a cargo das autoridades. Às autoridades sanitárias era também requerido que tomassem as necessárias providências de modo a que as farmácias estivessem providas

75 Diário do Governo, II série, n.233, p.3255-3256, 4/10/1918. 
dos medicamentos mais utilizados, devendo intimar as farmácias a não aumentarem os preços dos medicamentos.

O sexto preceito indicava a necessidade de organizar localmente a assistência e a caridade, sob o impulso, tutela e direcção das autoridades distritais e concelhias, assim como das câmaras municipais. As corporações locais tinham como tarefa chamar a atenção dos beneméritos, preparar reuniões e criar "comissões de socorro", cuja falta a portaria afirmava sentir-se. ${ }^{76}$

A 4 de outubro saía novo decreto, com a chancela da Direcção-Geral de Saúde. Em atenção ao "estado sanitário do país" proibia-se "a saída do país, tanto pela fronteira terrestre como via marítima de todas as drogas medicamentosas". ${ }^{77}$ A 6 de outubro de 1918 no decreto. $n^{\circ}$. 4.872, vindo da Direcção-Geral de Saúde, falava-se claramente da "actual epidemia de gripe que se encontra disseminada por todo o país" e procurava-se estabelecer um claro programa de resposta baseado na resposta epidemiológica tradicional. ${ }^{78}$ Por este diploma era nomeado um comissário geral do governo com poderes excepcionais, entre os quais os de requisição de serviços públicos, e de solicitar auxílios e a ajuda de colectividades públicas e particulares, que não podia ser recusada: foi Ricardo Jorge.

As epidemias de 1918 obrigaram a um enorme esforço financeiro. A verba total de créditos extraordinários levantados desde janeiro de 1918 até meio de novembro subiu a pouco menos de 2.142 contos. $^{79}$ Mas estes recursos seriam sempre escassos. A Direcção Geral da Saúde Pública procurou tomar, num curto espaço de tempo, diversas medidas para enfrentar o flagelo. Entre estas contaram-se: a devolução à clínica civil de médicos afectos ao serviço militar e o regresso ao serviço de médicos que já se haviam reformado; a mobilização dos estudantes finalistas das Faculdades de Medicina; a requisição de veículos automóveis particulares para o serviço médico-sanitário. Distribuíram-se géneros alimentares, como o pão e açúcar, e remédios recomendados, como o quinino e outras drogas. Deram-se subsídios em dinheiro a indigentes e instituíram-se "comissões de socorro" para recolher dádivas e exercer a beneficência. ${ }^{80}$ Também se tratou de fazer com que as farmácias estivessem providas dos medicamentos mais usados, de controlar os seus preços, distribuíram-se subsídios pelos distritos afectados pela epidemia, etc. ${ }^{81}$

76 Portaria de 2/10/1918. Diário do Governo, II série, n.233, p.3255-3256, 4/10/1918

77 Dec. n.4.871 de 4/10/1918. Diário do Governo, I série, n.217, p.1754, 5/10/1918

78 Dec. n.4.872 de 10/1918. Diário do Governo, I série, n.218, p.1755, 7/10/1918.

79 Para se ter uma ideia em termos comparativos, relembre-se o que já se afirmou, que para 1918-19 o Ministério do Trabalho, que tutelava a Direcção-Geral de Saúde, tinha orçamentado cerca de 390 contos para a Assistência Pública e menos de 300 para os hospitais civis. Diário do Governo, II série, n.55, p.800, 802, 11/03/1919.

80 JORGE, Ricardo. La grippe, p.35.

81 Instruções do Director-Geral da Saúde Pública. O Comércio do Porto, $1^{a}$ página, 1/10/1918. 
Fiquemos por aqui no que se reporta a créditos atribuídos e normas instituídas. Como seria o cumprimento efectivo destas normas? O Alto-Comissário que o governo tinha no norte, deslocou-se do Porto para o concelho (município) de Vila Real de Trás-os-Montes e, pelo seu relatório, o figurino terá sido seguido aí. Mobilizou-se o único automóvel que então havia na capital do distrito para transporte de médicos; ajustou-se o internamento dos doentes mediante subsídio no hospital da Misericórdia e o seu transporte pela Cruz Vermelha; estruturou-se a divisão de trabalho entre médicos e farmácias; despenderam-se verbas em subsídios vários e estabeleceu-se um receituário básico para enfrentar a doença. ${ }^{82}$

Mas o panorama afigura-se ser, no entanto, o de uma enorme carência de recursos, e de uma ultrapassagem das autoridades, sanitárias e outras, perante a rapidez e violência da epidemia. Um estudo feito sobre o Algarve, no sul, concluiu ser pouco o efeito das medidas tomadas pela administração central, e nomeadamente as da Direcção-Geral de Saúde. Diante de um cenário de carência generalizada - de alguns alimentos, de médicos, farmacêuticos e medicamentos, terá existido uma ruptura dos serviços administrativos e sanitários, impotentes diante da epidemia, enquanto a população estava presa de pânico. ${ }^{83} \mathrm{Um}$ outro estudo, sobre o município de Leiria, onde houve mortalidade elevada, dotado de uma cidade capital de distrito, detectou aí toda a série de carências. Desde as deficiências da população em matéria alimentar, às condições sanitárias deploráveis, sem água canalizada na cidade e muito lixo acumulado. Não havia médicos suficientes, faltavam farmacêuticos, vítimas da doença, e medicamentos essenciais. Houve necessidade de requisitar espaços para improvisar leitos, pois os dois hospitais da cidade, o civil e o militar, não eram suficientes para obviar às necessidades de internamento dos doentes, e recorrer ao serviço cívico de estudantes finalistas de Medicina. Tomaramse medidas para acalmar a população, proibindo o toque dos sinos - ou o das campainhas nos acompanhamentos dos enterros - para não provocar alarme. Mas não houve desinfecções. As autoridades políticas, sanitárias, militares e religiosas - tanto pela via da oração propiciatória, como pela da difusão de instruções em matéria de saúde - cooperaram no combate ao flagelo. E, sob a égide da principal autoridade política, o governador civil, constituiu-se uma Comissão de Assistência às Vítimas da Epidemia, já em inícios de novembro, destinada a apoiar os órfãos e os mais pobres. Algumas associações que actuam nas maiores cidades, como Lisboa e Porto - Cruz, Vermelha, Cruz Verde, Cruz de Malta... - não têm aqui qualquer

82 GARRETT, Almeida. Contra a epidemia de gripe pneumónica, em 1918, no norte do país, p.653-673.

83 GIRÃO, Paulo Jorge Marques. A gripe pneumónica no Algarve (1918). 
actividade. Nem açúcar havia para xaropes. Em conclusão, as autoridades não conseguiram responder minimamente à epidemia. ${ }^{84}$

Diante da violência da $2^{a}$ vaga, a capacidade da rede hospitalar existente, como sucedeu sintomaticamente com o Hospital do Rego, em Lisboa, onde se fazia o internamento, isolamento e tratamento dos portadores de doenças infecto-contagiosas, foi rapidamente excedida. Na cidade de Lisboa, por exemplo, no dizer do Director dos Hospitais Civis de Lisboa, "(...) uma cidade suja e infecta, sem higiene e quase sem água, rica de toda a casta de espécies mórbidas", houve que recorrer de novo a hospitais já abandonados, como o de Arroios, e de transformar em hospitais grandes e modernos estabelecimentos públicos, como o Liceu de Camões, ou requisitar edifícios a outros ministérios, como sucedeu com parte de um convento, também adaptado a hospital. ${ }^{85}$

No entanto, a incapacidade das estruturas sanitárias para lidarem com o flagelo não se limitou a um país com carências reconhecidas como Portugal, mas foi geral. Vejam-se os casos Espanha, onde as autoridades se referiram à falta de meios, de pessoal e de laboratórios, ${ }^{86}$ dos Estados Unidos da América, onde o Serviço Público de Saúde encarregado da defesa contra as doenças contagiosas não estava preparado para enfrentar um problema de tamanha magnitude, ${ }^{87}$ do Brasil, onde se reportou a incapacidade dos poderes públicos para fazer face à doença. ${ }^{88}$ A própria Grã-Bretanha, que possuiria uma das mais sofisticadas "máquinas de saúde pública" da época teria dado uma das respostas mais fracas à epidemia, na opinião de uma investigadora. ${ }^{89}$

Encontramos muito poucas referências, nas orientações oficiais, ao fecho de escolas, locais de culto, fábricas, grandes armazéns, transportes públicos, teatros ou cinemas. Sabemos, entretanto, que foram tomadas medidas nesta área, que escolas, públicas e particulares, liceus, universidades e escolas superiores fecharam. Em Lisboa a Escola Naval e a Escola de Guerra estiveram fechadas. ${ }^{90}$ Em Coimbra a sala de leitura da Biblioteca da Universidade também encerrara devido à "epidemia bronco-pneumónica

84 FRADA, João José Cúcio. A pneumónica em Portugal continental: estudo socioeconómico e epidemiológico com particular análise do concelho de Leiria. Lisboa: Sete Caminhos, 1998. Embora se saliente o papel positivo desempenhado por algumas autoridades, o diagnóstico para o Algarve é o da incapacidade destas para enfrentar a epidemia. GIRÃO, Paulo Jorge Marques. A gripe pneumónica no Algarve (1918), p.140-141.

85 ALVES, A. Lobo. Relatório do Director Geral dos Hospitais Civis. In: Relatórios e notícias sobre a epidemia de gripe pneumónica, p.6-7.

86 ECHEVERRI DÁVILA, Beatriz. La gripe española: la pandemia de 1918-19, p.140.

87 CROSBY, Alfred. America's forgotten pandemic, p.49.

88 GOULART, Adriana da Costa. Revisitando a espanhola: a gripe pandêmica de 1918 no Rio de Janeiro. Revista História Ciências Saúde - Manguinhos, Rio de Janeiro, v.12, n.1, p.101-42, jan-abr. 2005; SILVEIRA, Anny Jackeline Torres. A influenza espanhola e a cidade planejada: Belo Horizonte, p.65.

89 THOMKINS, Sandra M., The failure of expertise: public health policy in Britain during the 1918-1919 influenza epidemic. Social History of Medicine, 1992.

90 Sobre a Escola Naval ver: Dec. n.5033. Diário do Governo, I série, n.264, p.2116, 3/12/1918. A Escola de Guerra esteve fechada entre 3/10/1918 e 21/12/1918, levando a um complicado processo de reavaliação dos estudantes no ano seguinte de 1919. 
que então grassava com uma certa intensidade". ${ }^{91}$ Na sessão de 7.11.1918 o próprio parlamento sidonista, do qual estava excluídos os antigos partidos republicanos, votaria o seu enceramento até 3 de dezembro, por causa da epidemia de gripe.

Porém, em Lisboa, os "eléctricos" (bondes) continuaram a circular. O encerramento das estações do caminho-de-ferro deveu-se ao estado de doença dos seus funcionários, mais do que a quaisquer orientações de quarentena ou cordão sanitário; as estações foram submetidas a desinfecção, sem que se saiba em que extensão.

O director-geral da saúde pública defendeu a adopção de medidas que restringissem o contágio, como as grandes feiras e peregrinações, ou as escolas, mas mostrou-se contrário a um alargamento de proibições que incluíssem o fecho de teatros e cinemas, e, na sequência destes, presumivelmente cafés, igrejas, transportes colectivos, mercados, repartições, armazéns, fábricas. ${ }^{92}$ Não acreditava, nas suas palavras, que o isolamento nas cidades, ou em hospitais, pudesse conter o contágio de um vírus tão violento quanto o de 1918, que nem mesmo pouparia os países mais avançados do ponto de vista sanitário, e entendia que a vida económica e social devia continuar "(...) em todas as suas modalidades, incluindo as distracções, para não alimentar o isolamento e o pânico". ${ }^{93}$ Recomendava a assistência médica e social - e nomeadamente alimentar - e achava que desinfecções excessivas como as feitas com creolina e queimar barricas de alcatrão eram um desperdício inútil. ${ }^{94}$

Pode-se acrescentar que a proibição total de todos os grandes ajuntamentos contrariava a prática política do regime, que recorria à mobilização pública de massas em torno do líder como meio de propaganda. Porém, o não acatamento de medidas como o encerramento de lugares públicos ou a proibição de ajuntamentos, ou disposições contraditórias que autorizavam um determinado tipo de reuniões e interditavam outras não se limitou de modo algum a Portugal. Em Espanha, se houve cordões sanitários, e se o fecho de escolas e universidades públicas foi decretado, não houve unanimidade no fecho de salas públicas como teatros e cinemas e houve mesmo festas de touros. ${ }^{95}$ No Brasil, em São Paulo, as escolas particulares ainda continuaram activas depois das públicas terem sido encerradas; ${ }^{96} \mathrm{em}$ Belo Horizonte as escolas públicas e as faculdades fecharam, mas nem

91 Sobre a Biblioteca da Universidade de Coimbra ver Boletim da Biblioteca da Universidade de Coimbra, v.V, p.221, 1920.

92 JORGE, Ricardo. La grippe, p.32.

93 JORGE, Ricardo. La grippe, p.31-32

94 JORGE, Ricardo. La grippe, p.32-33.

95 ECHEVERRI DÁVILA, Beatriz. La gripe española: la pandemia de 1918-19, p.143-145; GALLO, Isabel Porras. Un reto para la sociedad madrileña, p.95-96.

96 BERTUCCI, Liane Maria. Influenza, a medicina enferma, p.106-113. 
todos os estabelecimentos de lazer estariam encerrados ${ }^{97}$ Os responsáveis brasileiros também achavam, na sua maioria, ${ }^{98} \mathrm{como}$ Ricardo Jorge ou como os espanhóis, por exemplo, ${ }^{99}$ que era impossível impedir a propagação de uma epidemia como aquela.

Mas a rapidez e violência do segundo surto de gripe pneumónica não foram os únicos factores que dificultaram a montagem de uma estrutura capaz de fornecer uma resposta concertada das instituições. Havia muitos médicos ausentes, adstritos ao serviço militar fora do país. O saber e capacidade médicos eram agora questionados, depois dos êxitos registados pela bacteriologia, que detectara a origem das doenças na actividade de microrganismos em finais do século XIX. ${ }^{100}$ Em Portugal, como em toda a parte, debateu-se a natureza da infecção, se era a dengue, se era causada pelo bacilo de Pfeiffer, se pela febre dos papatazes, ${ }^{101}$ havendo mesmo quem falasse em "peste pneumónica", como aliás em Itália, ${ }^{102}$ confundindo a influenza com uma manifestação antiga da peste bubónica, que afectava em particular o aparelho respiratório. ${ }^{103}$ Porém, a autoridade sanitária máxima portuguesa, prestigiadíssima, e que mesmo assim foi alvo de crítica, situava-se entre os que correctamente - pois muitos na comunidade científica na época e mesmo depois continuavam a apoiar a hipótese de Pfeiffer - achava que a causa da gripe era um vírus por identificar ${ }^{104}$ e que o único remédio seria a descoberta de uma vacina específica, como acontecera para a varíola. ${ }^{105}$ Também assim pensava a maioria dos médicos espanhóis, entre outros. ${ }^{106}$ Não fez, no entanto, tábua rasa, dos procedimentos clássicos da desinfecção - dos transportes públicos, dos estabelecimentos - recomendou a limpeza de casas e povoações, o isolamento dos doentes fosse nas suas casas, em hospitais, quartéis, colégios, prisões, hospícios. ${ }^{107}$ Porventura os isolamentos e quarentenas foram, como sugere Silveira, um ritual simbólico, uma cedência ao temor popular, apesar de o saber médico achar que eram ineficazes quaisquer medidas de profilaxia. ${ }^{108}$ Entretanto, podemos discernir nas explicações e medidas aventadas a coexistência entre dois tipos de explicações das epidemias: enquanto produto de uma configuração, definida pelo ambiente e pelas condições de vida (lembre-se a

97 SILVEIRA, Anny Jackeline Torres. A influenza espanhola e a cidade planejada, p.146-148.

98 SILVEIRA, Anny Jackeline Torres. A influenza espanhola e a cidade planejada, p.250.

99 ECHEVERRI DÁVILA, Beatriz. La gripe española: la pandemia de 1918-19, p.140.

100 PORTER, Roy. The greatest benefit to mankind: a medical history of humanity, p.428-461.

101 JORGE, Ricardo. A nova incursão Peninsular da Influenza. Portugal Médico, Porto, $3^{a}$ série, v.IV, n.6, p.436-443, junho de 1918; JORGE, Ricardo. La grippe, p.8-10.

102 TOGNOTTI, Eugenia. Scientific triumphalism and learning from facts: bacteriology and the 'Spanish flu' challenge of 1918. Social History of Medicine, v.16, n.1, p.97-110, em particular p.100, 2003

103 JORGE, Ricardo. La grippe, p.13-14.

104 JORGE, Ricardo. A nova incursão peninsular da influenza, p.442. O vírus apenas viria ser a ser identificado em 1933. Ver OLDSTONE, Michael B. A. Viruses, plagues and history, 1998, p.172-186.

105 JORGE, Ricardo. La grippe, p.34.

106 GALLO, Isabel Porras. Un reto para la sociedad madrileña, p.106

107 JORGE, Ricardo. La grippe, p.33-34.

108 SILVEIRA, Anny Jackeline Torres. A influenza espanhola e a cidade planejada, p.257, 251. 
atenção dada à higiene, alimentação, em particular dos pobres) e enquanto resultado da contaminação, do contágio. ${ }^{109}$

\section{A resposta dos agentes políticos}

O combate à epidemia foi dirigido de cima de forma hierárquica, através de um circuito que combinava os canais burocráticos e os serviços sanitários. A base - subdelegados de saúde - e os níveis intermédios - delegados - deviam reportar à direcção-geral a existência de epidemia. ${ }^{110} \mathrm{~A}$ opinião pública era informada por notas divulgadas pela direcção-geral de saúde ou pelas notícias de correspondentes locais.

As iniciativas locais, unindo autoridades à igreja e a beneméritos e outros notáveis e associações locais, como os bombeiros e, sobretudo, a Cruz Vermelha, obedeceram a apelos dimanados do centro político, mas sem que se montasse propriamente um esquema de enquadramento geral a nível nacional. Não cabe aqui a análise das motivações em que assentou a mobilização destes diferentes actores sociais. Mas deve referir-se que não podemos dar como assente que se assistiu exclusivamente a um movimento generalizado de altruísmo perante o flagelo. No Algarve, onde tal foi investigado, constatou-se existir a mobilização e o voluntariado de alguns, incluindo importantes industriais locais, mas também se concluiu haver inércia de personalidade influentes e indicou-se ter havido importantes agentes económicos do comércio e da indústria que aproveitaram o momento para a especulação económica. ${ }^{111}$

Podemos atentar na acção da Câmara Municipal de Lisboa. Durante a epidemia parece, aos olhos da documentação oficial e após uma leitura atenta das actas das sessões, ter sido diminuta, incidindo na manutenção da higiene dos espaços públicos, na atribuição de uma pequena verba para socorro aos doentes sem recursos, no fornecimento de caixões a preço do custo, e no providenciar medidas expeditas de enterramento dos cadáveres. ${ }^{112} \mathrm{E}$ esta autarquia dispunha de meios incomparavelmente superiores aos de qualquer outra. Mas não devemos generalizar.

A análise da resposta dos agentes políticos e administrativos do Estado exige que se tenha em conta circunstâncias estruturais como o estado da saúde e da assistência em Portugal, que já foi anteriormente referido, e conjunturais. Nestas incluem-se o tipo de regime fortemente personalizado

109 Havia uma terceira, "predisposição", que não se afigura ter sido relevante. Estas são propostas avançadas por ROSENBERG, Charles. Explaining epidemics and other studies in the history of medicine. Cambridge: Cambridge University Press, 1992, p.293-304.

110 Um exemplo da comunicação entre autoridades centrais e locais encontra-se em GIRÃO, Paulo Jorge Marques. A pneumónica no Algarve (1918).

111 GIRÃO, Paulo Jorge Marques. A pneumónica no Algarve (1918), p.150.

112 Actas das Sessões da Câmara Municipal de Lisboa, Comissão Executiva e Comissão Administrativa. Lisboa: Câmara Municipal de Lisboa, 1940. 
e autoritário da época e suas alianças, a conflituosidade política e social, os recursos financeiros e os meios disponíveis para combater a doença. Os recursos económicos e humanos eram escassos, num país que se endividava para combater os alemães na Europa e nas colónias de Angola e de Moçambique, para onde partiram não só muitos médicos como um amplo contingente de jovens adultos seleccionados entre os mais saudáveis. O próprio carácter dramático da irrupção da pneumónica, que representava um fenómeno que vinha revelar os limites da ciência médica, tem de ser tido em conta. Não podemos proceder a uma reconstituição do contexto de um modo completo no espaço deste texto, limitando-nos a fornecer elementos de síntese da nossa interpretação centrados agora na política específica do Sidonismo, o regime que duraria um ano, precisamente o das manifestações mais graves da "gripe pneumónica".

Apesar das alterações politicas introduzidas pelo golpe de estado que levou Sidónio Pais ao poder em 1917, as políticas de saúde pública e assistência mantiveram-se dentro de um figurino já conhecido e com a figura tutelar de Ricardo Jorge na chefia. Não se pôs em causa o modelo laico republicano, nem se fizeram grandes alterações na legislação existente.

As iniciativas estatais e de pendor claramente laico passariam apenas a ser complementadas com o regresso de algumas ordens religiosas e com o desenvolvimento de obras de caridade de pendor mais tradicional. ${ }^{113}$ Encabeçadas por figuras importantes da burguesia e dos meios católicos estas obras tiveram o apoio directo de Sidónio Pais e permitiram-Ihe constituir uma rede de clientela centralizada e personalizada. Foi este o caso da Obra de Assistência 5 de Dezembro, assim designada em homenagem ao golpe de Estado que levara ao poder o presidente Sidónio Pais. ${ }^{114}$ No contexto da epidemia, presidiu a uma comissão central de socorros encabeçada pelos indivíduos mais abastados do país - banqueiros, industriais, grandes comerciantes, grandes proprietários fundiários, plantadores coloniais, membros da alta aristocracia - coadjuvados pelas suas "senhoras". Muitos deles eram conhecidos pela sua hostilidade à República ou por posições conservadoras no seio desta. Durante a primeira reunião dela no palácio presidencial fez-se logo um peditório entre os presentes, que rendeu uma soma avultada e que constituía prova de como o poder se consubstanciava

113 As Doroteias, por exemplo, regressariam ao sector do ensino

114 A Obra de Assistência 5 de Dezembro seria criada em finais de Março de 1918 e a 10 de Julho de 1918 ampliaria a todas as capitais de distrito do continente e ilhas a actividade da Obra. Nos seus objectivos ficava clara a sua acção beneficente e complementar da do Estado na assistência em creches, maternidades, asilos, hospitais e estabelecimentos de educação (Decreto n.4.609 de 10 de Julho de 1918). Esta espécie de comissões de benemerência ficava assim com o desígnio claro de congregar esforços e de criar redes de notáveis próximas do regime e ligadas à sua figura máxima, com funções de intervenção social identificadas com o regime. 
não só nas estruturas formais, mas na rede de relações informais em torno do presidente. ${ }^{115}$

A Igreja - ela própria um agente político - uniu-se aos esforços deste poder, que não a afrontava como o anterior e que rompia com o anti-clericalismo notório que caracterizava até então a república instituída em 1910. A 5 de novembro de 1918 é publicada uma Provisão do cardeal patriarca de Lisboa, a figura mais importante da igreja católica portuguesa, acerca da epidemia. ${ }^{116}$ Nela o cardeal congratula-se com a acção do chefe de estado "que tanto zelo e infatigável actividade tem desenvolvido no louvável intuito de, com providencias efficazes e promptas, se acudir ao nosso paiz, actualmente ferido por uma cruelissima calamidade". ${ }^{117}$

Nesta provisão reitera o chamamento que fizera a 8 de outubro, não só para a realização e participação em preces públicas, procissões de penitência em vista a pedir a misericórdia divina, mas também para o desenvolvimento de actividades caritativas, para a participação em comissões de beneficência das paróquias, etc... ${ }^{118}$ Chama a atenção para a pobreza dos párocos e para a dificuldade em contribuírem a nível económico, mas logo acrescenta que podem cumprir o seu papel de uma outra forma, exortando e influindo no espírito dos paroquianos para que se "alistem na cruzada do bem". Com as suas instâncias e doutrinações tanto no templo como fora dele pode convencer os fiéis da total necessidade de seguirem cuidadosamente os meios que a "sciencia inculca, a hygiene aconselha e a auctoridade competente recomenda (...)". ${ }^{119}$ Com efeito, a Igreja e as suas organizações - como as associações de São Vicente de Paulo - parecem ter tido um papel importante na difusão das orientações da autoridade sanitária - a maioria, por certo, através da via oral, nas missas - ao mesmo tempo que recorria ao arsenal tradicional da explicação religiosa, em que a epidemia era explicada como castigo de Deus pelos pecados dos homens, e ao recurso à expiação pela via da oração.

O presidente da república, entretanto, construía a sua imagem de homem providencial. De comboio e automóvel, fazendo da velocidade da sua intervenção uma arma política, viajava pelo país, tomando a iniciativa de distribuir subsídios ou deixando-os mesmo nos locais afectados que visitava. ${ }^{120}$

\footnotetext{
1150 Século, 22 a 31 de outubro de 1918 e 6 de novembro de 1918. Uma vez que estes auxílios se destinavam explicitamente aos mais desfavorecidos, estas actividades implicariam o reconhecimento de que as situações de pobreza estavam ligadas ao aparecimento e propagação de doenças. SILVEIRA, Anny Jackeline Torres. A influenza espanhola e a cidade planejada, p.59.

116 CARDEAL PATRIARCA, António. Provisão. Vida Católica, ano IV, n.77, p.129-133, 5 de novembro de 1918

117 CARDEAL PATRIARCA, António. Provisão. Vida Católica.

118 CARDEAL PATRIARCA, António. Provisão. Vida Católica.

119 CARDEAL PATRIARCA, António. Provisão. Vida Católica.

120 Cf. O Comércio do Porto, $1^{a}$ página, 1-10-1918.
} 
Uma notícia de finais de setembro mostra bem como a especificidade deste regime presidencialista se revelava no combate à epidemia. Intitulada Em socorro dos doentes: o presidente da república no norte, ela dava conta da partida inesperada de madrugada de Sidónio Pais para Trás-os-Montes, "a fim de visitar e socorrer os enfermos pobres da "influenza que ali grassa". Levava com ele vinte sacas de açúcar - em grande medida provavelmente para a confecção de xaropes - trinta com arroz e cinquenta cobertores. $\mathrm{O}$ regime, efémero, e o bloco social e ideológico que o sustentava, viviam em torno da personalidade de Sidónio Pais. Mas esta viagem pode ser lida tanto como sintoma do protagonismo do presidente, como das carências da organização formal da assistência. Note-se, por fim, a escassez de socorros materiais que o comboio presidencial transportava, sinal iniludível das carências de abastecimento com que o governo se confrontava no contexto da epidemia. ${ }^{121} \mathrm{O}$ poder de um presidente que se queria forte enfrentava limites que a vontade pessoal não podia suprir. Os limites do próprio estado em proporcionar alimentos ou conforto, afinal algumas das poucas medidas recomendadas face ao flagelo pelo seu director-geral da Saúde, revelam-se flagrantemente nesta notícia.

Entretanto, a epidemia foi um móbil do combate político. O Mundo, jornal do Partido Democrático na oposição, e que estava, como todos os outros, submetido à censura, criticou o governo, "um governo de ricos para explorar o pobre", e chamou a atenção, no que não foi o único, para a necessidade de promover o isolamento dos doentes e medidas profiláticas, criticando as autoridades por o não fazerem, insistindo na insuficiência de recursos em pessoal médico, em medicamentos e alimentação. Entretanto, acusou o governo do republicano Sidónio de ter cancelado as comemorações oficiais do 5 de outubro - data da proclamação da república - para ganhar o apoio dos monárquicos, que lhe era necessário, e não para evitar o contágio pela epidemia, como invocara, pois permitira as sessões de comemoração populares e deixara abertos teatros e cinematógrafos. ${ }^{122}$ Podia-se acrescentar que a 26 de outubro, em plena força da epidemia, o governo permitiu a realização de um evento mundano em Lisboa, no Teatro Nacional: "a grande exposição de crisântemos". ${ }^{123}$

\section{Conclusão}

A epidemia de pneumónica ocorreu num país que enfrentava enormes dificuldades de natureza económica, política e sanitária. Não vale a pena repisar as primeiras, conhecidas de todos os historiadores do período, e

121 Cf. O Século, 24-9-1918

122 Por causa da epidemia - o governo não festeja a República. O Mundo, n.6438, 8-10-1918.

123 O Século, 27-10-1918. 
agravadas pelas circunstâncias de penúria do abastecimento e de açambarcamento de géneros para especular com a subida de preços. Politicamente, o regime de Sidónio Pais está a caminho do estertor. O próprio fim vitorioso da guerra - o Armistício é de 11 de novembro de 1918 - promovida em Portugal pelos seus principais opositores indiciava o seu fim. O mesmo outono da pneumónica assistiu a uma greve geral (em novembro) e a uma tentativa de insurreição militar promovida pelos seus adversários (em outubro). Sidónio seria morto a tiro a 14 de dezembro de 1918.

As respostas do governo e dos agentes encarregues da saúde pública estão estritamente determinadas, por um lado, pelo carácter imprevisto da pandemia, mesmo num país habituado a distintas epidemias. Perante este factor exógeno, a resposta dos agentes políticos e das autoridades ligadas à saúde pública foi marcada por factores ligados ao evento, à conjuntura e de tipo estrutural.

O episódio epidémico revelou a impotência do conhecimento científico para debelar o flagelo, o que retirou eficácia à acção de médicos e autoridades de saúde pública. A própria rapidez com que a epidemia se propagou contribuiu para acentuar a fragilidade das suas respostas.

O peso da conjuntura política revela-se tanto na acção do próprio presidente, jogando o seu próprio carisma na intervenção pessoal, no recurso a alianças com sectores sociais com capacidade de mobilização de recursos, como, por parte dos adversários do regime, no aproveitamento da epidemia para o combate a quem que estava no poder. Mas a conjuntura económica, agravada pelas circunstâncias da guerra, de carência de recursos de todo o tipo - financeiros, alimentares, medicamentosos, humanos (pessoal médico) - fez-se sentir poderosamente. E, para além desta, revelava-se a estrutura de longa duração de um país pobre, onde a existência de algumas figuras e instituições relevantes no campo higienista e médico punha por contraste em relevo as carências que se continuavam a sentir. 